\title{
The Role of Journalists in Building Optimism in the Small Industry Community During the Corona Pandemic (Study: Formation of a Post For Journalists Covering Covid-19 for the South West Region of Aceh)
}

\author{
Muzakkir ${ }^{1}$, Allisman $^{2}$, Putri Maulina ${ }^{3}$, Ikhsan $^{4}$ \\ 1,3 Department of Communication, Universitas Teuku Umar, Indonesia \\ ${ }^{2}$ Department of Economy, Universitas Teuku Umar, Indonesia \\ ${ }^{4}$ Department of Public Administration, Universitas Teuku Umar, Indonesia \\ Correspondent: muzakkir@utu.ac.id
}

\section{Received : August 08, 2021 \\ Accepted : August 25, 2021 \\ Published : October 31, 2021}

Citation: Muzakkir, Allisman, Maulina, P., Ikhsan (2021). The Role of Journalists in Building Optimism in the Small Industry Community During the Corona Pandemic (Study: Formation of a Post For Journalists Covering Covid-19 for the South West Region of Aceh). Ilomata International Journal of Social Science, 2(4), 308-318.

https://doi.org/10.52728/ijss.v2i4.377

\begin{abstract}
The corona virus pandemic has made some small industrial communities complain, plus there is confusing news information, so that some people feel nervous in dealing with the spread of the corona virus. The study in this research is basically a field research (field research) and literary (library research), with a historical and multidisciplinary approach. Existing data, the authors analyze using a comparative method in a qualitative paradigm, through snowball sampling. Through this method, researchers hope to collect information needed by the small industrial community, so that they are motivated and enthusiastic in moving their business in the midst of the Corona pandemic. The role of the media is not only to report, but also to deny hoax information and untrue information, moreover the media has an important and strategic role in following the development of reliable information related to Covid-19 reporting, as a trusted source for the community towards the era of adaptation of new habits (new normal). ). The presence of journalists presenting news about aid programs, business opportunities, and product marketing facilities for small industry players in circulation and online is one of the breakthroughs that can foster new optimism and hope (expectations) among small industry players in the midst of their business slump due to the pandemic. corona. The final goal of this study, the author tries to get a concrete picture of the roles and responsibilities of journalists in building the optimism of the small industrial community during the corona pandemic.
\end{abstract}

Keywords: The Role of Journalists, Small Industrial Society, During the Covid-19 Period

(c) This is an open access article under the
CC-BY 4.0 license.

\section{INTRODUCTION}

During the corona pandemic, people's activities, especially small industrial communities, are decreasing, so that it has an impact on the economic aspects of society in general (Bai et al., 2021). Therefore, the role of journalists in conveying information to the public during the 
corona pandemic is highly expected, even though the task of journalists is full of various risks and is vulnerable in the midst of the spread of the corona virus outbreak (Susanti \& Widajatun, 2021). However, the journalist profession is required to always be at the forefront who always works to build public optimism in carrying out daily activities, especially small industrial communities (Nordhagen et al., 2021; Shafi et al., 2020).

The chairman of the National Press Council, Mohammad Nuh, emphasized that the press must be a clearing house in conveying information to the general public, especially the small industrial community and against hoaxes. It's time, all parties, all stakeholders show their sincerity to protect a free, independent, professional and responsible press from various threats and restrictions. The press has the ability to convince the public of information and promotions that have an impact on the sale of business products, because the development of the press today is more oriented towards industries that can generate profits and increase people's income (Fachruddin, 2019; Kusumaningrat \& Kusumaningrat, 2006). The corona pandemic has made some small industrial communities complain. Recently, a study stated that Covid-19 will make Indonesia experience a decrease in the percentage of economic growth by $0.1 \%$ in 2020 . Several companies have adopted a work from home policy, and have also decided to lay off their employees, up to mass layoffs. The effects of the storm of layoffs and workers being laid off have made production capacity decline. This condition has caused raw materials for the production of small industries and households to experience scarcity and extreme price increases. For example, the SME sector of cake and bread maker, which is confused by the soaring price of eggs and sugar. As a result, the selling price of the product also increases (Trinh et al., 2020).

As a reference, the author also uses previous research related to this research, which was researched by Nadia Amalian Rahmah (2020), with the title, "The Impact of Covid-19 on Micro, Small, Medium Enterprises (MSMEs) in Indonesia". The results of his research, small industrial business actors experience difficulties in raw materials because they must be purchased outside the province or abroad. As we know, several provinces have implemented regional quarantines and several countries have implemented lockdowns. A total of 63 cooperatives and small industrial enterprises or 6 percent, stated that they had difficulty in raw materials. As happened in Banten, DKI Jakarta, DIY, West Kalimantan, East Kalimantan, West Java, East Java and Central Java.

The corona pandemic is one of the major events that has received serious public attention. The recommendation for social distancing to avoid the spread of the corona virus more broadly, has an impact on decreasing buying and selling activities and transactions in the community, thus making the turnover of industry players decrease. "MSMEs have experienced a drastic decrease in income, so they have difficulty paying fees. These costs include employee/honorary salaries, business capital, daily living expenses, and other necessities (Rahmah, 2020).

The decline in production capacity for the industrial community due to Covid-19 is very pronounced, and for the industrial community it is difficult to obtain raw materials due to soaring prices and limited access to exports and imports. This option is considered risky, considering that currently people's purchasing power is increasingly sluggish, especially small industrial communities that move with a small number of workers, and use simple technology such as industrial household appliances, furniture, traders, workshops, tailors and embroidery, 
traditional cake vendors. Aceh, know tempeh due to the corona pandemic. This can be observed around the Meulaboh City Market-Johan Pahlawan District, Meureubo District-West Aceh Regency and its surroundings including in several other areas in the South West Region of Aceh.

For the next guide, the author also takes an understanding from the subsequent previous research conducted by Solten Rajagukguk (2020), with the title, "The Role of Mass Media Against Society During the Covid-19 Pandemic" . From his research, it is stated that the role and responsibility of mass media journalists to the community during the corona pandemic is very large and important. Through the role of journalists in reporting events, the public can receive information as a step to protect themselves and avoid exposure to Covid 19. Mass Media as a tool used to convey information messages to the public, so that people are more careful in living their lives during the corona pandemic.

The success of journalists in tackling the Covid-19 pandemic is largely determined by the success of building communication. For this reason, it is the responsibility of journalists to bridge the process of information flow so that the industrial community avoids the presence of various confusing news information, which can make people panic, fear and be anxious in the face of the spread (pandemic) of the corona virus. In the midst of public pessimism about the impact of a prolonged pandemic that paralyzes the economy of individuals and society, the presence of journalists who present news about aid programs, business opportunities, and marketing facilities for products of small industry players in circulation and online is one of the breakthroughs can foster new optimism and hope (expectations) among small industry players in the midst of their business slump due to the pandemic. Based on the above, the author examines the roles and responsibilities of journalists in the midst of the corona pandemic in an effort to build optimism in the industrial community.

\section{METHOD}

The research studies in this work are basically field research and literature research. The data sources of this research are based on qualitative research, relying on primary sources related to the main issues. The approach used in this research is a historical and multidisciplinary approach. After that, the existing data, the authors analyzed using a comparative method in a qualitative paradigm. The goal is to find points of similarities and differences so that they can produce conclusions that can be scientifically justified.

In this study, qualitative methods are also used which are closely related to the interpretive paradigm which can be seen in several characteristics: (a) Qualitative research focuses on words, not numbers. This method is carried out by observing and interviewing the small industry community and with journalists on a condition or event; (b) Researcher involvement; The main instrument of qualitative research is that the researcher is closely involved with the people being studied (L. J. Moleong, 2018).

In the concept of a qualitative approach, researchers focus on data and facts that occur and require development that is supported by certain theories. Meanwhile, the case study method requires an in-depth and more specific focus. 
The Role of Journalists in Building Optimism in the Small Industry Community During the Corona Pandemic (Study: Formation of a Post For Journalists Covering Covid-19 for the South West Region of Aceh)

Muzakkir, Allisman, Maulina, Ikhsan

Then this research was conducted in the South West Region of Aceh (Barsela), where there is a Post for Journalists Covering Covid-19. In this study, the time used ranged from 8 months (April to November 2021).

The sampling method in qualitative research is divided into two parts, namely, the sample unit and the sampling technique (Berger, 2019; Pawito, 2008; Ruslan, 2017). The sample unit relates to what is actually represented in the research observations. In this regard, the author defines journalists and the small industrial community as the sample research units, where journalists have the role and responsibility to convince and build public optimism through the delivery of information in driving the economy during the corona pandemic.

The sampling technique is concerned with how to determine who (the subject) is the representative in the research observation. From this understanding, the author uses a sampling technique by means of snowball sampling (Pawito, 2008), namely the sampling technique is done by selecting key informants who sequentially take recommendations on who will be the next informant. The snowball sampling technique is used with the consideration that the author does not fully know or know the subject of the sample unit (journalists and small industry communities) to be studied.

Based on the qualitative method, the main instrument of this research is the author himself who goes directly to the field to seek information through observation and interviews. Broadly speaking, data sources in qualitative research can be grouped into two types (Pawito, 2008), namely:

a. Observation: Observation is direct observation of the role of journalists in building the optimism of the small industrial community in the midst of the Covid-19 pandemic. In accordance with the qualitative methodology and research needs, the authors held interactions and dialogues with journalists and the small industry community to obtain empirical data relevant to the direction of the discussion. For this reason, researchers used the help of observational instruments, namely field notes, event recording tools such as recorders and camera photos.

b. Interview: At this stage, the author conducted interviews with several small industry communities and journalists from several Covid-19 Covering Journalist Posts in the South West Region of Aceh (Barsela) which had been selected in advance based on the sampling technique as described previously. The type of interview used is in-depth interviews (in-depth interviews) with manual techniques interview (interview guide). The reason for using this type and technique of interview is to get depth and develop data from informants.

c. Library and Document Review: At this stage the authors carry out data collection techniques through literature review (literature review). Literature review in qualitative research aims to be a reference for important concepts, as well as an explanation of the theoretical aspects included in the focus of the discussion. While the study of documents in the form of diaries, reports, artifacts, photos, and so on.

As for data analysis in this study was conducted inductively (from data to theory). The steps of data analysis in the case study, namely organizing information, reading the entire information, making a detailed description of the case and its context, the researcher establishes a pattern and 
The Role of Journalists in Building Optimism in the Small Industry Community During the Corona Pandemic (Study: Formation of a Post For Journalists Covering Covid-19 for the South West Region of Aceh)

Muzakkir, Allisman, Maulina, Ikhsan

looks for relationships between several categories, then the researcher interprets and develops natural generalizations of the case, both for researchers as well as for its application to other cases, and presents it in a narrative manner (Bungin, 2017).

\section{RESULT AND DISCUSSION}

\section{Journalists Build Community Optimism Small Industry Actors}

The coronavirus pandemic has made some small industrial communities complain. In conveying information to the public, especially to small industrial communities, the press must be a clearing bouse to fight hoaxes. The press has the ability to convince the public to listen to information and promotions so that it has an impact on their product sales efforts, because the development of the press, both print and online, today's television and radio is more oriented towards industries that can generate profits and increase people's income (Fachruddin, 2019).

The chairman of the National Press Council, Mohammad Nuh emphasized, "The commemoration of World Press Freedom Day" May 3, 2020 is the right momentum for journalists to help the industrial community because the media space is filled with messages dealing with the corona virus outbreak. The press must continue to observe, supervise, and criticize various government policies that are based on data, facts, and presented proportionally while adhering to the journalistic code of ethics.

Journalists working in the South West of Aceh (Barsela) seek to encourage and build good relations with the Regional Government (Pemda), stakeholders, and with the ranks of private companies in the Barsela region to concentrate on business development programs for small and medium-sized industrial communities in the future. Covid-19 pandemic. Journalists also invite the Regional Government (Pemda) to conduct training for small industrial businesses (homescale businesses). "We will continue to do the same between journalists and the local government in encouraging the business of the industrial community during the corona pandemic," said resource person Rizwan, SE., MA (Journalist of Serambi Indonesia Daily in Nagan Raya-Aceh Regency).

According to Journalistic Practitioner, Yarmen Dinamika, the role of journalists in increasing public trust is an effective instrument for disseminating programs that touch the poor, especially during the corona pandemic. Through the mass media as a funnel of information, positive news can be narrated with the aim of raising the spirit and creativity of the small industrial community in moving their business in the midst of the corona pandemic.

One form of the journalist's role as expected, the Regional Government continues to carry out programs that favor the small industrial community in driving businesses during the Corona Pandemic. The form of the local government's attention can be observed through news publications by journalists in the media, such as information that as many as 80 Small and Medium Industries (IKM) and Small and Medium Enterprises (UKM) players in Aceh Barat Regency, Aceh Province, received business equipment assistance, to support economic activities in the middle of the world. Covid-19 pandemic. "The work equipment assistance that we provide is expected to be able to develop the entrepreneurship of the small industrial community in West Aceh Regency," said Zulyadi, Head of the West Aceh Industry, Trade, Cooperatives and SMEs Office. After the researcher confirms, the business capital assistance is transferred directly to the accounts of small industry players. The business capital assistance for the small industrial 
community was obtained from the Ministry of Cooperatives on a proposal from the West Aceh SME Service. "For 2021, all business capital has been distributed for the majority of small industry players in West Aceh," said Zulyadi.

The work equipment assistance provided by the West Aceh Regional Government was in the form of carpentry and workshop equipment for each of the 60 recipient groups. Meanwhile, for people who run small businesses such as multipurpose sewing machines/overlocking machines, there are 50 recipient groups. For embroidery machine business actors, there are 7 (seven) groups of recipients. By granting the business equipment grant, the West Aceh Regional Government hopes to increase the ability of small industry players to utilize industrial technology, increase production, and increase economic welfare for small business groups, said Ramli.MS, Regent of West Aceh Regency.

\section{The Real Role of Journalists for Small Industrial Society}

National Press Day, which is commemorated on February 9, 2021, with the theme, "Rising from the Pandemic", the role of journalists as an acceleration of change is urgently needed in handling the corona pandemic, so as to be able to bring changes in people's behavior in a positive direction. In addition, the commemoration of the national press day is a momentum for learning to the public and a torch for knowledge. Journalists for the South West Region of Aceh (Barsela) who became research informants such as Riski Bintang Rahmanda, Rahmad, Taufik Zass, Dian Saputra, Syamsul Rizal, often receive complaints from the small and medium industry community. "Our command post is often visited by small industrial communities to submit their complaints via us, such as tofu and tempe traders, spice traders, and Acehnese cake traders," responded Syamsul Rizal, member of the Covid-19 Covering Journalist Post, Ujong Baroh Village., Meulaboh-West Aceh Regency.

The complaints from the small industrial community are generally problems with business capital. Through journalists, they asked to be able to submit their complaints to the local government and to entrepreneurs so that they could help with capital to run their businesses during the corona pandemic. "We accommodated their complaints, we conveyed them to the regent and to the heads of related offices, both directly and in press meetings," said Syamsul. "Journalists also often remind the local government when there are certain moments, so that the government continues to increase its concern for the small industrial community," said Orian, journalist for Puja TV Aceh. In fact, several journalists admitted that they had planned (designed) news stories that raised the spirit of business for small industry players to be published in various media, both print, electronic and online media.

On the other hand, journalists also conveyed information through the media about the efforts of the "Southwest Aceh (Abdya) District Government of Aceh Province, to market various products of Micro, Small and Medium Enterprises (MSMEs) online through the Abdya Creative Information Center (Tokopika) Online Store application, such as seeds jengkol, nutmeg seeds, and various other superior commodity seeds. The launch of the tokopika.com application was carried out by the Regent of Abdya, Akmal Ibrahim. The goal is to make it easier for MSME actors to market their products to the public in order to get a wider market potential. The budget for the development of the tokopika application is sourced from the 2020 APBK. "The Abdya Regency Government's attention to MSMEs is also inseparable from the motivation of journalists to provide advice and input to the Abdya Government. 
News Director of Beritasatu Media Holdings (BSMH), Primus Dorimulu said, this year the Indonesian economy experienced an extraordinary contraction. The "pain" of the economy is experienced not only by micro, small and medium enterprises, but also by corporations. The corona pandemic has hit all lines. Therefore, it is not enough for the mass media to function in disseminating accurate information but must also be able to build public optimism.

Journalists also conveyed information that Teuku Umar University (UTU) and Syiah Kuala University (USK) Banda Aceh in collaboration with the District Government (Pemkab) of West Aceh, launched (launching) small industrial business products and Online Store which is a Regional Partnership Program (PKW). together, in Kuala Bubon, Samatiga District, West Aceh, on September 11, 2021. "Collaboration like this is a tangible manifestation of the Tridharma of Higher Education (PT) for the small industrial business community directly," said Mursyidin, Deputy Chancellor III UTU . the products of industrial society efforts have focused on the preparation of processed entering a wider market segment, with a distribution license (SPP-IRT) and also Online Store.

With the distribution permit, the small industrial community's business has met the quality standards of food processing, and can be circulated more widely in the market, including modern markets such as super markets and malls that continue to mushroom in Aceh. Universities collaborate with the government, "We know that the Covid-19 condition that has not subsided has affected all businesses, some have been stagnant, and some have even gone out of business. However, we are grateful that these small industrial business actors in Kuala Bubon can continue to survive and be productive, especially with guidance from the campus, "explained Arisman, a government official at the West Aceh Trade Office.

\section{Small Industry Business Actors Still Exist}

Several small industrial business actors who still exist to move their businesses in the midst of the corona pandemic, can be observed around the Jalan Negara-West Aceh Regency and Nagan Raya Regency. A number of small industry players have experienced ups and downs in running their business during the corona pandemic. Although many small and medium-sized industrial business actors get capital and work tools from the local government to run a business, from interviews, during the corona pandemic there are still small industrial communities who have not received business capital assistance from the local government. "We didn't get business capital, maybe we didn't submit an application to the local government during the corona pandemic. In the future, we will try to ask for it by submitting a request", confessed Rukaiyah, a seller of Acehnese cakes, Langung Village, Meureubo District, West Aceh.

Based on the observations of researchers in several business markets in the districts of Aceh Jaya, Southwest Aceh, South Aceh, and Aceh Singkil, they also experienced the same thing. There are small industrial business actors in a number of districts in Barsela who have gone out of business during the corona pandemic. This is due to the lack of working capital, people's purchasing power decreases. The decline in people's purchasing power, according to information from several small industrial business players in South Aceh Regency, is due to the financial factor of buyers and some people rarely go out of their homes to shop at the market during the corona pandemic. This is confirmed by a statement written by Nadia Amalian Rahmah (2020), that during the corona pandemic many people work from bome, do activities, worship and isolate themselves at home. Small industry business actors experienced a drastic 
The Role of Journalists in Building Optimism in the Small Industry Community During the Corona Pandemic (Study: Formation of a Post For Journalists Covering Covid-19 for the South West Region of Aceh)

Muzakkir, Allisman, Maulina, Ikhsan

decrease in income so that they had difficulty paying expenses, such as salaries or employee salaries, difficulties in increasing business capital, and other needs. At least, 917 small and medium-sized industrial enterprises experienced a decline in sales. These are found in DKI Jakarta, Banten, West Java, Central Java, East Java, Yogyakarta Special Region, North Sumatra, West Sumatra, Riau, Bengkulu, Bali, West Kalimantan, East Kalimantan, North Sulawesi, Central Sulawesi, South Sulawesi, South Sumatra and South Kalimantan .

Other small industrial business actors such as confection. Confection is a small household scale industry which is a place for making apparel such as shirts, pants, t-shirts and so on. Confectionary clothing is managed individually and in groups. "Confection is one of the business of making clothing using standard sizes, to serve the needs of the people who need it. Clothing is made with size classifications, namely S, M, and L. While the special size uses an extra L size (Rianto, 2003).

The confectionery business is another strategy taken by small industrial business actors in several areas within the Barsela region. Some of the small industrial communities still exist to sell around the finished clothes made by convection. Sales of convection clothing to people's homes are carried out using two-wheeled and four-wheeled vehicles.

"We and our family are trying to sell around the confectionery. This way can be a little smoother, rather than waiting for buyers. During the corona pandemic, people's purchasing power decreased greatly, so we took steps to sell to people's homes. Thank God, the results are good," said Abdullah, a traveling confectioner's clothing vendor in West Aceh Regency.

\section{Supporting and Inhibiting Factors}

Factors that support and hinder journalists' efforts in building the optimism of the small industry community during the corona pandemic include:

\section{A. Supporter}

a) Mutual me motivation. Journalists in carrying out their profession need to receive advice, input and encouragement from the Chief Editor, editors and editorial staff, especially during the corona pandemic.

b) We fully support the performance of journalists on duty during the Covid-19 pandemic in increasing enthusiasm and business encouragement for small and medium industrial communities. Journalists must survive and always make a positive contribution to the public," said Syarifuddin, Head of SKK Migas, when opening a webinar for journalists, on September 10, 2020.(d). Meutya Hafid (senior journalist), Suryopratomo (Covid-19 Handling Task Force) and TV journalist, Amanda Komaling, provide support, almost all industries affected by Covid-19, especially small industries. Even though they are affected by COVID, journalists must continue to carry out their role as enlighteners, not making news they like.

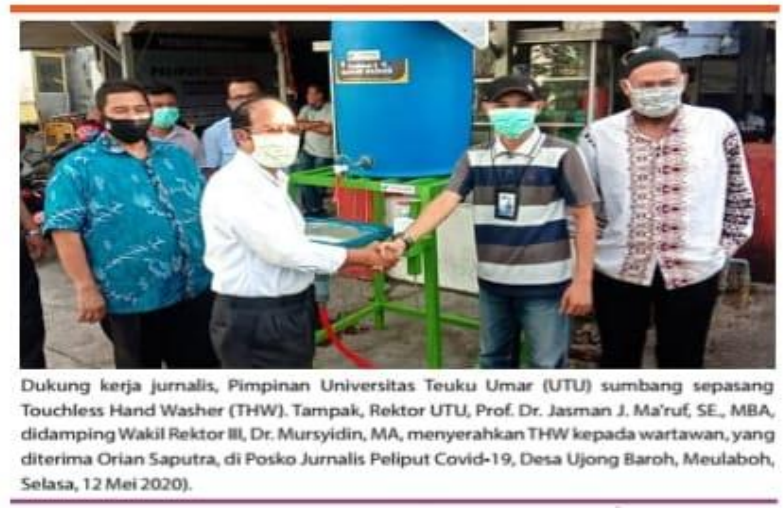


Support from universities (P') also 'flows' to the performance of journalists. This was seen by the Chancellor of the University of Teuku Umar (UTU), Prof. Dr. Jasman J. Ma ruf handed over the Touchless Hand Washer (THW), which is a non-touch hand washing device, to journalists working in the midst of the corona pandemic. The THW was handed over at the Covid-19 Covering Journalists Post, Meulaboh, West Aceh Regency.

\section{B. Inhibitor}

According to Arba'iyah Satriani, Lecturer of Journalism at the Faculty of Communication Sciences, Islamic University of Bandung, who is also a former Republika journalist, journalists in carrying out their journalistic duties during the current corona pandemic are a dilemmatic job, both for journalists and for resource persons met by journalists. . "That is the common thread that was conveyed in the Webinar, "Covering Covid-19: Reporting coronavirus from the US, Hong Kong and Mainland China Rose" organized by the Institute for Journalism and Society, Hong Kong Baptist University on April 10, 2021. The panelists from America, Hong Kong and China, conveyed information about the obstacles as well as the strategies carried out by journalists when covering the Covid-19 pandemic which is currently still taking place in various countries including Indonesia.

A Chinese journalist, Ran An, said that apart from having a good educational background, journalists' research abilities are very crucial in covering cases of the corona pandemic. This awareness will make journalists more careful in seeking information in the field. After all, just like the medical personnel who are on the front line in the fight against Covid-19, the journalists are also the front line guards on the other side. In order for the public to be calm, especially the industrial community, the information conveyed should fulfill the wishes of the community.

Another obstacle, said Meutya Hafid, citing a survey released by the International Federation of Journalists (IFJ), as many as 866 journalists experienced salary cuts, job losses, and salary delays during the Covid-19 pandemic. While the results of another survey conducted by the Faculty of Economics and Business (FEB) Padjadjaran University showed that $45.92 \%$ of journalists experienced symptoms of depression and $57.14 \%$ experienced general boredom. "To be able to survive the Covid-19 pandemic, journalists must be able to adapt and be innovative." Therefore, one of the obstacles for journalists who work in South West Aceh (Barsela) in carrying out his journalistic profession in the midst of the corona pandemic, it is necessary to prioritize the principle of prudence in reporting by continuing to carry out health protocols and through the media being observant and sensitive in capturing things that are troubling the public by presenting the meaning of the news and then informing the media. However, still trying to prioritize professionalism in the news an. Besides always coordinating, compromising fellow journalists in an effort to maintain and prioritize safety at work.

\section{CONCLUSION}

It is the responsibility of journalists in bridging the process of information flow so that the industrial community avoids the presence of various confusing news information, which can make people panic, fear and be anxious in the face of the spread (pandemic) of the corona virus. In the midst of public pessimism about the impact of a prolonged pandemic that paralyzes the economy of individuals and society, the presence of journalists who present news about aid programs, business opportunities, and marketing facilities for small industrial business 
The Role of Journalists in Building Optimism in the Small Industry Community During the Corona Pandemic (Study: Formation of a Post For Journalists Covering Covid-19 for the South West Region of Aceh)

Muzakkir, Allisman, Maulina, Ikhsan

products in circulation and online is one of the breakthroughs. can foster new optimism and hope (expectations) among small industry players in the midst of their business slump due to the pandemic.

The local government continues to carry out programs that favor small industrial communities during the corona pandemic. This can be observed through news publications by journalists in the media, such as attention to Small and Medium Industries (IKM) and Small and Medium Enterprises (UKM) players in Aceh Barat Regency, Aceh Province, obtaining capital and business equipment assistance, to support community economic activities. industry in the midst of the Covid-19 pandemic. Journalists often remind the local government both in press meetings and at certain moments, so that the government continues to increase its concern for the small industrial community. In addition, universities (PT) also provide real support for the performance of journalists, such as the provision of Touchless Hand Washers to journalists working in the midst of the corona pandemic.

Several small industrial business actors in the districts of Aceh Jaya, West Aceh, Nagan Raya, Southwest Aceh, South Aceh, and Aceh Singkil, experienced ups and downs in moving their business, some were forced to go out of business during the corona pandemic. This is due to the lack of working capital and also the people's purchasing power has decreased. The decline in people's purchasing power is due to the financial factors of buyers and some people rarely leave their homes to shop at the market due to the corona pandemic.

The researcher suggests to journalists and small industrial communities who carry out their daily activities:

1. Use health protocols in conducting business activities and transactions during the corona pandemic.

2. A urnalis keep their functions and roles as lightening, though wracked pandemic information providers corona, the precautionary principle and always follow the health protocol in conducting journalistic activities

3. So that the industrial community is calm, peacefully convey information that fulfills the wishes of the community and get rid of confusing information.

\section{REFERENCE}

Bai, C., Quayson, M., \& Sarkis, J. (2021). COVID-19 pandemic digitization lessons for sustainable development of micro-and small- enterprises. Sustainable Production and Consumption, 27, 1989-2001. https://doi.org/10.1016/j.spc.2021.04.035

Berger, A. A. (2019). Media and Communication Research Methods (5th ed.). SAGE Publications, Inc. https://us.sagepub.com/en-us/nam/media-and-communication-researchmethods/book259331

Bungin, B. (2017). Metodologi Penelitian Kualitatif (B. Bungin (ed.); 2nd ed.). PT Rajagrafindo Persada. https://www.rajagrafindo.co.id/produk/metodologi-penelitian-kualitatif-burhanbungin/

Fachruddin, A. (2019). Journalism Today (A. Fachruddin (ed.)). Prenada Media Group. https:/ /opac.perpusnas.go.id/DetailOpac.aspx?id=1218245

Kusumaningrat, H., \& Kusumaningrat, P. (2006). Jurnalistik: Teori dan Praktek (1st ed.). Remaja 
The Role of Journalists in Building Optimism in the Small Industry Community During the Corona Pandemic (Study: Formation of a Post For Journalists Covering Covid-19 for the South West Region of Aceh)

Muzakkir, Allisman, Maulina, Ikhsan

Rosdakarya. https://opac.perpusnas.go.id/DetailOpac.aspx?id=680769

Moleong, J. L. (2008). Qualitative Research Methodology. Rosdakarya Youth.

Moleong, L. J. (2018). Metodologi Penelitian Kualitatif (38th ed.). Remaja Rosdakarya. https:/ /opac.perpusnas.go.id/DetailOpac.aspx?id=1133305

Nordhagen, S., Igbeka, U., Rowlands, H., Shine, R. S., Heneghan, E., \& Tench, J. (2021). COVID-19 and small enterprises in the food supply chain: Early impacts and implications for longer-term food system resilience in low- and middle-income countries. World Development, 141, 105405. https://doi.org/10.1016/j.worlddev.2021.105405

Pawito. (2008). Penelitian Komunikasi Kualitatif (Pawito (ed.)). PT LKiS Pelangi Aksara. https:/ / books.google.co.id/books?id=zN5iDwAAQBAJ\&printsec $=$ frontcover\&dq=zN5i DwAAQBAJ\&hl=id\&sa $=$ X\&ved $=0$ ahUKEwiKpbqUof3nAhW56nMBHYFJBSkQ6AEIK

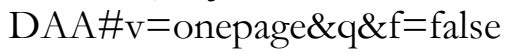

Rahmah, N. A. (2020). The Impact of Covid-19 on Micro, Small, Medium Enterprises (UMKM) In Indonesia. Universitas Islam Antasari. https://www.academia.edu/42694142/Karya_Tulis_Ilmiah_Nadia_Amalia_Rahmah

Rajagukguk, S., \& Olifia, S. (2020). The Role of Mass Media on Society During a Pandemic Covid-19. Jurnal Sosial Politik Universitas Satya Negara Indonesia, 1(1), 42-52. https://isip.usni.ac.id/jurnal/Solten.pdf

Rianto, B. (2003). Dasar-dasar Pembelanjaan Perusahaan (4th ed.). BPFE. http:/ /kin.perpusnas.go.id/DisplayData.aspx?pId=7399\&pRegionCode=UN11MAR\&pCli entId $=112$

Ruslan, R. (2017). Metode Penelitian Hubungan Masyarakat dan Komunikasi (R. Ruslan (ed.); 7th ed.). Rajawali Pers. https://opac.perpusnas.go.id/DetailOpac.aspx?id=1135559

Shafi, M., Liu, J., \& Ren, W. (2020). Impact of COVID-19 pandemic on micro, small, and medium-sized Enterprises operating in Pakistan. Research in Globalization, 2, 100018. https://doi.org/10.1016/j.resglo.2020.100018

Susanti, N., \& Widajatun, V. W. (2021). MSMEs Understanding of Taxation During the COVID-19 Pandemic. Journal of Innovation and Community Engagement, 2(1), 35-46. https://doi.org/10.28932/jice.v2i1.3689

Trinh, Q. L., Morgan, P. J., \& Sonobe, T. (2020). Investment behavior of MSMEs during the downturn periods: Empirical evidence from Vietnam. Emerging Markets Review, 45, 100739. https://doi.org/10.1016/j.ememar.2020.100739 